This manuscript version is the "Accepted Author Manuscript" - the final published article detail is below and may be accessed via the DOI link provided:

Tomlinson, D, Rivett, M.O., Wealthall, G.P., Sweeney, R., 2017. Understanding complex LNAPL sites: Illustrated handbook of LNAPL transport and fate in the subsurface. Journal of Environmental Management, 204, 748-756 https://doi.org/10.1016/j.jenvman.2017.08.015

\title{
Understanding Complex LNAPL Sites: Illustrated Handbook of LNAPL Transport and Fate in the Subsurface
}

\author{
Derek W. Tomlinson, P.E., P.Eng., BCEE (GEI Consultants, Philadelphia, USA) ${ }^{1}$ \\ Michael O. Rivett, Ph.D. (GroundH2O Plus Ltd, Birmingham, UK; University of Strathclyde, Department \\ of Civil \& Environmental Engineering, Glasgow, UK) \\ Gary P. Wealthall, Ph.D. (Geosyntec Consultants, Guelph, Canada) \\ Rob Sweeney, Ph.D. (CL:AIRE, UK)
}

\begin{abstract}
\footnotetext{
${ }^{1}$ Corresponding Author:

Derek W. Tomlinson, P.E., P.Eng., BCEE

Principal | Science, Engineering \& Technology Leader

GEI Consultants, Inc.

100 Campbell Boulevard, Suite 103

Exton, PA 19341

Direct.+1.484.872.7018

Mobile.+1.267.218.0835

dtomlinson@geiconsultants.com
}

The goal of the paper is to highlight the management of the complexities and risks for light non-aqueous phase liquid (LNAPL) sites, and how the "Illustrated Handbook of LNAPL Transport and Fate in the Subsurface" (CL:AIRE, London. ISBN 978-1-905046-24-9. http://www.CL:AIRE.co.uk/LNAPL; LNAPL illustrated handbook) is useful guidance and a tool for professionals to understand these complexities and risks. The LNAPL illustrated handbook provides a clear and concise best-practice guidance document, which is a valuable decision support tool for use in discussions and negotiations regarding LNAPL impacted sites with respect to the risks of LNAPL sites. The LNAPL illustrated handbook is a user-friendly overview of the nature of LNAPL contamination in various geological settings including unconsolidated, consolidated, and fractured rock environments to best understand its fate and behavior leading to the appropriate management and/or remedial approach of the two major risks associated with a LNAPL source. As a source term, LNAPL has chemicals that form dissolved- and vapor-phase plumes, which are referred to as composition-based risks; and being a liquid there is the risk that the source may expand impacting a greater volume of the aquifer, which are referred to as saturationbased risks. There have been significant developments in recent years on the understanding of the complex behavior of LNAPL and associated groundwater and vapor plumes; however, the state of 
practice has often lagged these improvements in knowledge. The LNAPL illustrated handbook aids the site investigator, site owners, and regulators to understand these risks, and understand how these risks behave through better conceptual understanding of LNAPL transport and fate in the subsurface.

\section{Keywords}

risk; composition; saturation; LNAPL; light non-aqueous phase liquid; conceptual site model 


\section{Introduction}

Releases of fuels such as gasoline, diesel, heating oils, jet fuel, lubricants, collectively referred to as light non-aqueous phase liquids (LNAPLs), have long been management concerns related to their risks posed to human-health and the environment from contact with chemicals in or direct contact with LNAPL. LNAPLs are among the most commonly encountered organic contaminants in the subsurface environment due to their pervasive use, poor historic disposal practices, accidental release during handling, storage or transfer at fuel manufacturing facilities, refineries, bulk-product terminals, gas stations, airports, military bases, and from smaller scale storage at domestic properties, industrial facilities and farms (CL:AIRE, 2002, 2014; Molins et al., 2010; USEPA, 2009; USGS, 1998). Typically, these are releases from underground and above ground storage tanks, conveyance piping, and overage filling. Unfortunately, LNAPLs released into the subsurface have been managed inappropriately for many years and decades after their release without proper understanding of the risks associated with these liquid sources. This relates to ill-defined and weak conceptual site models (CSMs) of the LNAPL source, for which rationale risk-management strategies can be built. The goal of the paper is to highlight the management of the complexities and risks for LNAPL sites, and how the "Illustrated Handbook of LNAPL Transport and Fate in the Subsurface" (LNAPL illustrated handbook; Figure 1) is a best-practice guidance and tool for professionals to understand these complexities and risks pertaining to LNAPL behavior in the subsurface (CL:AIRE, 2014).

Shown in Figure 2 is a simplified CSM of a LNAPL release; the primary concern with a LNAPL release is to ensure there are no emergency conditions (see 1, Figure 2). LNAPLs like other sources have chemicals that contribute towards the dissolved- and vapor-phase pathways that may potentially affect a receptor (see 2, 3a, \& 3b, Figure 2). Risks related to toxicity of the chemicals that diffuse and dissolve from LNAPL are known as composition-based risks and are feeding both dissolved- and vapor-phase plumes like other source terms that may pose a potential impact to receptors (ASTM, 2014; CL:AIRE, 2014; ITRC, 2009a; Johnston, 2010). LNAPL is also a liquid source. As a liquid, and if sufficient in quantity or saturation (i.e., fraction of the pore space occupied by LNAPL), there are perceived risks related to the ability of the liquid to spread and impact a greater volume of the aquifer (see 4, Figure 2) or has the potential to directly contact a receptor, or simply the aesthetic, reputation, or the regulatory requirement to remove the LNAPL to the maximum extent practicable (see 5, Figure 2). This potential for a LNAPL to spread is referred to as saturation-based risk (CL:AIRE, 2014; ITRC, 2009a). Management of these two risks, composition and saturation, ultimately manages the primary risks and provides a more sustainable and risk-based management of LNAPL releases.

Most LNAPL sites can be considered complex (ITRC, 2017); however, understanding the risks and their management from release to closure is critical and guidance like the LNAPL illustrated handbook assists site investigators, site owners, and regulators in conducting site investigations and risk assessments, and in selecting the appropriate remediation and management approaches.

\section{Complexity of LNAPL Sites}

The amount of detail necessary within a LNAPL CSM increases with complexities of the hydrogeologic and plume conditions, and concerns related to potential risks. Simply, the more complex the site conditions are to understand and the more concerns there are with sensitive receptors and other risks, there is more value on a thorough CSM for the best management decision. ASTM E2531 attempted to show this degree of complexity graphically (Figure 3); wherein, as drivers or potential risk factors like offsite plume, sensitive receptors, toxicity, and site use and community issues increase, and complexity of hydrogeologic and plume factors increase the more complex the site, and the greater detail is necessitated in development of the CSM (ASTM, 2014). A weight of evidence determination is made by a 
professional on the level of detail to understand the complexities and drivers related to both the composition- and saturation-based risks.

\section{Saturation-based risks: LNAPL transport and distribution in porous media}

LNAPL behavior and movement, commonly referred to as migration, in the subsurface is complex. Migration of LNAPL within the vadose zone from a release behaves similarly to a dense non-aqueous phase liquid (DNAPL) release (Charbeneau et al., 1999, 2000; Kueper et al., 2003; Mercer and Cohen, 1990). If only a small amount of LNAPL is released, migration will cease within the vadose zone as mass is immobilized within soil pores due to retentive capillary forces (CL:AIRE, 2014). For larger discrete releases, LNAPL will drain under gravitational influence and will undergo spreading controlled by lithology of the overburden or structure of the bedrock geology. Unlike DNAPLs that sink once reaching the water table, LNAPLs being lighter than water, the saturated aquifer will impede, but not completely prevent, their migration deeper due to both increasing water content and associated buoyancy forces arising from the LNAPL-water fluid density contrast (CL:AIRE, 2014). Driving forces of a LNAPL release will penetrate below the water table, and lateral spread of LNAPL near the water table is determined principally by the LNAPL head gradient (i.e., the height of the LNAPL release above the water table, LNAPL head) due to the LNAPL release that is initially greater than the water table gradient; however, the LNAPL gradient will dissipate with time eventually leading to LNAPL footprint stabilization (see Figure 4). Stabilization depends on the type of LNAPL with low viscosity LNAPLs (e.g., gasoline and diesel) taking weeks to months, and high viscosity LNAPLs (e.g., heating oil) requiring months to years to eventually stabilize (CL:AIRE, 2014). For distinct releases of LNAPL, the LNAPL will eventually become stable, and will form a source of varying levels of saturation within the pores of the formation. The LNAPL saturation at the leading edge will drop in saturation to below residual (i.e., fraction of the pore space occupied by LNAPL that cannot be mobilized under an applied gradient), and through balances of factors at the leading edge due to insufficient LNAPL head to exceed pore entry pressure, lower saturations (i.e., residual), and natural source zone depletion (NSZD) processes, further explanation is provided in the LNAPL illustrated handbook.

Historically the distribution of LNAPL within the subsurface was believed to be an immiscible liquid floating on top of water like a pancake (USEPA, 1996). This thinking overestimated the volume of LNAPL within the subsurface, assumed that all LNAPL formed a continuous layer of complete saturation filling the entire porosity by LNAPL (i.e., $100 \%$ of the porosity filled with LNAPL). This earlier understanding failed to fully recognize the controls of capillary forces and greatly over-predicted the amount of LNAPL within the subsurface and the amount of potentially recoverable LNAPL.

Farr et al (1990) and Lenhard and Parker (1990), provided a paradigm shift in the understanding of LNAPL distribution within the subsurface. They considered capillary pressures of various liquid phases and developed functions that related fluid contents of the porous media to capillary pressures. Extending these concepts, the LNAPL saturation profile at the water table interface of an unconfined homogeneous isotropic aquifer is predicted to assume a shark fin like shape (see Figure 5) under equilibrium conditions when capillary pressures considerations are invoked (CL:AIRE, 2014; Farr et al., 1990; ITRC, 2016; Lenhard and Parker, 1990). A detailed review of these concepts is provided in the LNAPL illustrated handbook.

As shown on Figure 5, when LNAPL saturation is above residual saturation a monitoring well through the LNAPL source will typically show measurable thickness of LNAPL (see Figure 5c); whereas, when the LNAPL saturation is below residual the same well will typically not observe LNAPL (see Figure 5d) (ITRC, 2016). Residual saturation is discontinuous and immobile LNAPL under prevailing conditions 
and not typically hydraulically recoverable (ASTM, 2014). The portion of the LNAPL distribution above residual is referred to as the mobile or recoverable fraction (i.e., LNAPL saturation fraction of the pore space occupied by LNAPL above residual is referred to as mobile, and under applied gradient or higher LNAPL saturations is potentially migrating), as depicted on Figure 6 (CL:AIRE, 2014; ITRC, 2016). This mobile fraction is the source of saturation-based risks; however, the entire LNAPL source including the residual is the source of composition-based risks. Work by Pickell et al. (1966), indicated that the residual saturation is a percentage or fraction of the saturation and that it varied based upon the maximum saturation, this percentage or fraction (i.e., f-factor) was further defined upon soil type (Kueper et al., 1993; Steffy et al., 1997). LNAPL residual saturation based upon this f-factor is depicted as the dashed line on Figures 5 and 6. Further details on residual saturation are provided in the LNAPL illustrated handbook. Note the idealized conditions presented in Figures $\mathbf{5}$ and $\mathbf{6}$ are not typical as shown in Figure 7 depicting measured and modeled homogeneous and heterogeneous cases (Beckett and Lundegard, 1997; Huntley et al., 1994a, 1994b).

The LNAPL distribution that accumulates in the subsurface is the 'source zone' of contamination. It comprises both immobile residual LNAPL, which is trapped in pore spaces by capillary forces; and mobile (i.e., recoverable) LNAPL, which exists as a continuous liquid across interconnected pores and can migrate when subjected to a sufficient driving forces. The potential that mobile LNAPL may migrate is managed as a saturation-based risk. The LNAPL illustrated handbook further covers LNAPL migration in porous media as well as fractured rock including factors influencing LNAPL distribution and redistribution due to water table fluctuations.

\section{Composition-based risks: LNAPL properties and mass transfer}

Many environmental practitioners have encountered LNAPL in the subsurface, and LNAPL sites are typically among the sites with the longest management history due to their complexity of chemical composition in a multi-phase LNAPL-water-air environment, and in some cases, they are addressing saturation-based risks through LNAPL recovery which does not address the chemicals within the LNAPL.

As detailed within the LNAPL illustrated handbook, many LNAPLs released to the environment are a complex mixture of organic compounds (CL:AIRE, 2014). For example, gasoline is a complex mixture of over 500 hydrocarbons that may have between 5 to 12 carbons and include in greatest amounts alkanes, and to a lesser extent alkane cyclic and aromatic compounds, as well as alkenes (Dabelstein et al., 2007). Many LNAPLs have additives formulated into the mixture such as ethanol and historically methyl tert butyl ether (MTBE), as well as others, to enhance and extend their performance as fuels or lubricants. Some of the additive components are primary composition-based risk drivers due to their greater toxicity.

LNAPL being a source, these various chemicals within the source form dissolved- and vapor-phase plumes, which drive composition-based risks associated with LNAPL. Details of the types and uses of commonly encountered LNAPLs, elaborating on the key physical-chemical properties such as density, viscosity, interfacial tension against water, composition, aqueous solubility, vapor pressure and wetting behavior that influence their environmental fate are defined within the LNAPL illustrated handbook.

The physical-chemical properties of individual compounds within a LNAPL mixture control rates of partitioning from LNAPL to the gas and aqueous phases (CL:AIRE, 2014). This mass transfer leads to the development of vapor-phase plumes in the vadose zone above the water table and shallow dissolvedphase plumes in groundwater laterally flowing beneath the water table. Some of these processes are conceptualized in Figure 8. The LNAPL illustrated handbook provides further details on the LNAPL 
mass transfer process and the fate and transport of the respective plumes that are produced, including the role of natural attenuation in the management of the composition-based risks.

\section{Conceptual models of LNAPL behavior}

The goal of site characterization is to understand the source-pathway-receptor processes for the identified LNAPL source. Site characterization is used to develop and refine the CSM understanding. With respect to a LNAPL release, characterization is typically focused on understanding the area of the site with the LNAPL source zone. In addition to understanding the geological and aquifer features of the site, the investigation aims to establish the distribution of LNAPL, if LNAPL is stable or expanding, chemical composition, and to identify pathways to potential receptors.

There are two main drivers in the management of LNAPL-impacted sites that inform site characterization needs of the CSM (CL:AIRE, 2014):

- to understand potential risks posed to receptors by both current and plausible future mobile LNAPL distributions (i.e., saturation-based risks), and migration of their associated dissolvedand vapor-phase plumes (i.e., composition-based risks); and

- to understand LNAPL constraints on remediation selection, design and operation which often requires more targeted investigation and pilot testing.

Development of CSMs are typically an iterative process during the site investigation and assessment phases, with a site-specific level of detail related to the complexity of environmental conditions at a site, regulatory framework, and site management objectives. Information typically required to develop a CSM for a LNAPL-impacted site may include (ASTM, 2014; CL:AIRE, 2014; EA, 2001; ITRC, 2009a):

- $\quad$ site setting (historical and current): land use, LNAPL use/storage (including amounts and periods) and release mechanisms, groundwater classification and use, receptor presence and proximity, etc.

- geological and hydrogeological information/setting;

- LNAPL physical (density, viscosity, interfacial tension, vapor pressure) and chemical (constituent chemistry, solubility and mole fractions) properties;

- LNAPL body spatial distribution (vertical and horizontal);

- LNAPL mobility and body stability information;

- LNAPL recoverability information;

- associated dissolved-phase and vapor-phase plume information; and

- LNAPL natural source zone depletion processes.

Central to the LNAPL illustrated handbook and management of risks posed is development of CSMs of LNAPL transport and fate across a comprehensive range of common hydrogeological systems including both unconsolidated and bedrock environments to understand the various complexities of these liquid sources. The development of the individual CSMs are supported by the various sections of the LNAPL illustrated handbook including: Section 2: Types of LNAPL and their properties; Section 3: LNAPL transport and distribution; and Section 4: LNAPL mass transfer and plume fate. These are considered the hub from which CSMs may be developed that fundamentally support both the characterization and investigation of sites and the management and remediation of sites designed to address unacceptable composition- and saturation-based risks. Various exemplar hydrogeological environments that could exist based upon commonly encountered aquifer material and flow characteristics are summarized on Table 1. These cover intergranular sediments and bedrocks of contrasting permeability and porosity types, and made (artificial) ground. The annotated exemplar CSMs summarize LNAPL migration and stabilized 
distribution of LNAPL, and an understanding of the dissolved- and vapor-phase pathways; thus, providing an understanding of the composition- and saturation-based risks within the various geological environments. An example for cemented fractured sandstone is shown on Figure 8. Detailed narratives and illustrations of exemplar hydrogeological environment CSMs are provided in the LNAPL illustrated handbook for beach sands, marine clays, glacio-fluvial sands and gravel, glacial till, granite/igneous rock, karst limestone, cemented sandstone/gritstone, chalk, shale/mudstone, sandstone, and made ground/backfill (Table 1).

\section{Management of Composition- and Saturation-based Risks}

As previously noted, LNAPL when released into the subsurface poses risks, which can be a considerable technical and management challenge (ASTM, 2014; CL:AIRE, 2014; ITRC, 2017). The requirement for remediation may be driven by a range of concerns related to the composition- and/or saturation-based risks. These risks alone are complex to understand, and factoring in the geological and hydrogeological heterogeneity of the subsurface, and more so in bedrock, the complexity of the understanding of the LNAPL source is further complicated with respect to their management and potential remediation objectives. The LNAPL illustrated handbook provides details on these differences.

Where unacceptable risks are confirmed then the development of a remedial strategy evaluates the options to mitigate these risks. This may include treatment of the source, action to break the pathway and/or protection of the receptor. The identification of a suitable remedial technology is then undertaken via a feasibility study that includes a range of criteria including assessment of technical effectiveness, cost, durability, practicality and increasingly, sustainability.

Central to understanding these remedial objectives is the relationship between LNAPL mass removal and risk reduction; in particular, the expected impact of changing reducing the composition- and saturationbased risks on down-gradient dissolved concentrations and plume longevity as summarized on Figure 9 (ITRC, 2009a; Johnston, 2010). Anticipated changes that may occur due to either a reduction in LNAPL composition (concentrations) or saturation (timescale) are illustrated and demonstrate the importance of understanding these changes in relation to the remedial objectives (CL:AIRE, 2014).

For saturation-based risks, these are typically managed through direct LNAPL removal via mass removal methods such as interceptor trenches, skimmer wells, single/dual well total fluids pumping, vacuum enhanced recovery, with other methods detailed within the LNAPL illustrated handbook. As noted in Figure 9, these mass removal methods do not address the composition-based risks, but rather aid in reducing and minimizing the concern that the LNAPL source term will expand further. Defining when to initiate LNAPL recovery is typically assessed through measurement of LNAPL transmissivity (ASTM, 2013; CL:AIRE, 2014; Charbeneau et al., 2016; ITRC, 2009a, 2016,), and for ceasing recovery measures of LNAPL transmissivity and the use of decline-curve analysis are typical (Poston and Poe, 2008; Sun, 2015).

Composition-based remediation is typically via phase change remedial methods, which are aimed at removal of toxicity of chemicals within the immobile residual phase following removal of the saturationbased risks but not exclusively. The LNAPL illustrated handbook provides details on various remedial approaches including soil vapor extraction and bioventing, air sparging and biosparging, in situ bioremediation, and in situ chemical oxidation.

Passive remedial methods to address the low levels of dissolved- and vapor-phase composition-based risks, and the nuisance-levels of saturation-based risks like LNAPL sheens from near or below residual levels of remaining LNAPL, include monitored natural attenuation to address dissolved-phase 
groundwater composition-based risks and residual LNAPL saturation through NSZD, which simply recognizes that LNAPL source zones deplete naturally (CL:AIRE, 2014; ITRC, 2009b; Johnson et al., 2006; Wiedemeier et al., 1999). NSZD is not only a passive means of managing remaining compositionand saturation-based risks, it is also a baseline metric that is useful to understand if added LNAPL mass removal measures are necessary, as research has noted LNAPL removal rates in the range of 100 to 1,000 gallons/acre/year (CL:AIRE, 2014; ITRC, 2009b; Johnson et al., 2006; Lundegard and Johnson, 2006; McCoy et al., 2015; Shiota et al., 2011). The LNAPL illustrated handbook provides further details on management and remedial processes.

\section{Closing}

The LNAPL illustrated handbook provides a blend of technical detail and real world conceptualization of the LNAPL problem and appropriate methods to investigate and manage both composition- and saturation-based risks. It is a strong management tool that facilitates access to a wealth of detailed research, guidance, and case study literature in relation to concerns of LNAPL releases within both unconsolidated and bedrock media (Table 1). The practitioner and research communities will find the LNAPL illustrated handbook of great use, and it also provides a valuable educational resource to others having a less direct interest or specialized knowledge.

\section{Acknowledgements}

Production of the LNAPL illustrated handbook was funded by Shell Global Solutions (UK) and supported by the Environment Agency. We thank the leadership of our colleague and editor Michael O. Rivett, $\mathrm{Ph} . \mathrm{D}$. of GroundH2O Plus (formerly the University of Birmingham), as well as the successful collaboration of the co-authors including: Derek W. Tomlinson, P.E., P.Eng., BCEE of GEI Consultants (formerly Geosyntec Consultants); Steve Leharne, Ph.D. of the University of Greenwich; Steven F. Thornton, Ph.D. of the University of Sheffield; Alan Thomas of ERM; and Gary P. Wealthall, Ph.D. of Geosyntec Consultants. Thank you also to the input and guidance of the Steering Board including Jonathan W.N. Smith, Ph.D. of Shell Global Solutions UK; Sanjay Garg, Ph.D., of Shell Global Solutions USA; Alwyn J. Hart, Ph.D, of Environment Agency; Rob Sweeney, Ph.D. of CL:AIRE; and Peter J. Zeeb, Ph.D. of Geosyntec Consultants. Thank you also to ASTM International (ASTM), Interstate Technology \& Regulatory Council (ITRC), and Contaminated Land: Applications in Real Environments (CL:AIRE) for permission to reprint and use of the Figures and tables presented within this paper. The

LNAPL illustrated handbook is available as a free download from the CL:AIRE website: http://www.CL:AIRE.co.uk/LNAPL.

\section{References}

ASTM, 2013. ASTM E2856-13, Standard Guide for Estimation of LNAPL Transmissivity, ASTM International, West Conshohocken, PA, 2013. https://www.astm.org/Standards/E2856.htm

ASTM, 2014. ASTM E2531-06 (2014), Standard Guide for Development of Conceptual Site Models and Remediation Strategies for Light Nonaqueous-Phase Liquids Released to the Subsurface, ASTM International, West Conshohocken, PA, 2014. https://www.astm.org/Standards/E2531.htm

Beckett, G.D., Lundegard, P.D., 1997. Practically impractical - The limits of LNAPL recovery and relationship to risk. Conference Proceedings of the 1997 Petroleum Hydrocarbons \& Organic Chemicals in Ground Water. Houston, Texas, National Ground Water Association \& American Petroleum Institute 
Charbeneau, R.J., Johns, R.T., Lake, L.W., McAdams, M.J., 1999. Free-Product Recovery of Petroleum Hydrocarbon Liquids. American Petroleum Institute, API Publication Number 4682

Charbeneau, R.J., Johns, R.T., Lake, L.W. McAdams, M.J., 2000. Free-Product Recovery of Petroleum Hydrocarbon Liquids. Ground Water Monitoring \& Remediation, 20: 147-158. doi:10.1111/j.17456592.2000.tb00280.x

Charbeneau, R.J., Kirkman, A., Rangaramanujam, M., 2016. API LNAPL Transmissivity Workbook: A Tool for Baildown Test Analysis - User Guide. American Petroleum Institute, API Publication 4762, April 2016. http://www.api.org/oil-and-natural-gas/environment/clean-water/groundwater/lnapl/transmissivity-workbook

CL:AIRE, 2002. Site characterisation in support of monitored natural attenuation of fuel hydrocarbons and MTBE in a chalk aquifer in Southern England. CL:AIRE Case Study Bulletin, CSB 1. http://www.CL:AIRE.co.uk/component/phocadownload/category/3-case-studybulletins?download=3:casestudybulletin01

CL:AIRE, 2014. An illustrated handbook of LNAPL transport and fate in the subsurface. CL:AIRE, London. ISBN 978-1-905046-24-9. http://www.CL:AIRE.co.uk/LNAPL

Dabelstein, W., Reglitzky, A., Schütze, A., Reders, K. 2007. Automotive Fuels. Ullmann's Encyclopedia of Industrial Chemistry. doi:10.1002/14356007.a16_719.pub2

EA, 2001. Guide to good practice for the development of conceptual models and the selection and application of mathematical models of contaminant transport processes in the subsurface. EA NGWCLC Rep. NC/99/38/2. https://www.sepa.org.uk/media/147777/csm-guidance-from-ea.pdf

Farr, A.M., Houghtalen, R.J., McWhorter, D.B., 1990. Volume estimation of light nonaqueous phase liquids in porous media. Groundwater 28: 48-56. doi:10.1111/j.1745-6584.1990.tb02228.x

Huntley, D., Hawk, R.N., Corley, H.P., 1994a. Nonaqueous phase hydrocarbon in a fine-grained sandstone: 1. Comparison between measured and predicted saturations and mobility. Groundwater, 32: 626-634. doi:10.1111/j.1745-6584.1994.tb00898.x

Huntley, D., Wallace, J.W., Hawk, R.N., 1994b. Nonaqueous phase hydrocarbon in a fine-grained sandstone: 2. Effect of local sediment variability on the estimation of hydrocarbon volumes. Groundwater, 32: 778-783. doi:10.1111/j.1745-6584.1994.tb00919.x

ITRC, 2009a. Evaluating LNAPL remedial technologies for achieving project goals. Interstate Technology and Regulatory Council, LNAPLs Team. http://www.itrcweb.org/GuidanceDocuments/LNAPL-2.pdf

ITRC, 2009b. Evaluating natural source zone depletion at sites with LNAPL. Interstate Technology and Regulatory Council, LNAPLs Team. http://www.itrcweb.org/GuidanceDocuments/LNAPL-1.pdf

ITRC, 2016. Light Nonaqueous-Phase Liquids: Science, Management, and Technology Two Day Workshop. Interstate Technology and Regulatory Council, LNAPLs Team. 5 to 6 April 2016, Atlanta, GA.

ITRC, 2017. Remediation Management of Complex Sites. Interstate Technology and Regulatory Council, Remediation Management of Complex Sites Team. http://www.itrcweb.org/GuidanceDocuments/RCMS-1.pdf 
Johnston, C.D., 2010. Selecting and assessing strategies for remediating LNAPL in soils and aquifers. CRC for contamination assessment and remediation of the environment, CRC Care Technical Report No.18. http://www.crccare.com/files/dmfile/CRCCARETechReport18SelectingandassessingstrategiesforremediatingLNAPLinsoilsandaquifers2.pdf

Johnson, P.C., Lundegard, P., Liu. Z., 2006. Source zone natural attenuation at petroleum hydrocarbon spill sites: I. Site-Specific Assessment Approach. Ground Water Monitoring \& Remediation, 26: 8292. doi:10.1111/j.1745-6592.2006.00114.x

Kueper, B.H., Redman, D., Starr, R.C., Reitsma, S., Mah, M., 1993. A field experiment to study the behavior of tetrachloroethylene below the water table: spatial distribution of residual and pooled DNAPL. Groundwater, 31: 756-766. doi:10.1111/j.1745-6584.1993.tb00848.x

Kueper, B.H., Wealthall, G.P., Smith, J.W.N., Leharne, S.A., Lerner, D.N., 2003. An illustrated handbook of DNAPL transport and fate in the subsurface. Environment Agency R\&D Publication 133, Bristol, UK. http://eprints.whiterose.ac.uk/90412/1/DNAPL handbook final.pdf

Lenhard, R.J., Parker, J.C., 1990. Estimation of free hydrocarbon volume from fluid levels in monitoring wells. Groundwater, 28: 57-67. doi:10.1111/j.1745-6584.1990.tb02229.x

Lundegard, P.D., Johnson, P.C., 2006. Source Zone Natural Attenuation at Petroleum Hydrocarbon Spill Sites - II: Application to a Former Oil Field. Ground Water Monitoring \& Remediation, 26: 93-106. doi:10.1111/j.1745-6592.2006.00115.x.

Mercer, J.W., Cohen, R.M., 1990. A review of immiscible fluids in the subsurface: properties, models, characterization and remediation. Journal of Contaminant Hydrology, 6(2): 107-163. doi: 10.1016/0169-7722(90)90043-G

McCoy, K., Zimbron, J., Sale, T., Lyverse, M., 2015. Measurement of Natural Losses of LNAPL Using $\mathrm{CO}_{2}$ Traps. Groundwater, 53: 658-667. doi:10.1111/gwat.12240.

Molins, S., Mayer, K.U., Amos, R.T., Bekins, B.A., 2010. Vadose zone attenuation of organic compounds at a crude oil spill site - interactions between biogeochemical reactions and multicomponent gas transport. Journal of Contaminant Hydrology, 112: 15-29. doi:10.1016/j.jconhyd.2009.09.002

Pickell, J.J, Swanson, B.F., Hickman, W.B., 1966, Application of Air-Mercury and Oil-Air Capillary Pressure Data in the Study of Pore Structure and Fluid Distribution, Society of Petroleum Engineers Journal, 6(1): 55-61. doi:10.2118/1227-PA

Poston, S.W., Poe Jr., B.D., 2008. Analysis of Production Decline Curves. Society of Petroleum Engineers. ISBN: 978-1-55563-144-4, 175 pp.

Sale, T., 2003. Answers to Frequently Asked Questions About Managing Risk at LNAPL Sites, API Soil and Groundwater Research Bulletin Number 18, May 2003. http://www.api.org/oil-and-naturalgas/environment/clean-water/ground-water/lnapl/lnapl-faqs

Sihota, N.J., Singurindy, O., Mayer, K.U., 2011. $\mathrm{CO}_{2}$-Efflux Measurements for Evaluating Source Zone Natural Attenuation Rates in a Petroleum Hydrocarbon Contaminated Aquifer. Environmental Science \& Technology, 2011, 45(2): 482-488. doi:10.1021/es1032585. 
Steffy, D.A., Barry, D.A. Johnston, C.D., 1997. Influence of antecedent moisture content on residual LNAPL saturation. Journal of Soil Contamination, 6(2): 113-147. doi:10.1080/15320389709383552

Sun, H., 2015. Advanced Production Decline Analysis and Application. Gulf Professional Publishing, Waltham, MA. ISBN: 978-0-12-802411-9, 352 pp.

USEPA, 1996. How to Effectively Recover Free Product at Leaking Underground Storage Tank Sites: A Guide for State Regulators. EPA-510-R-96-001, EPA OSWER, NRMRL, Washington, DC, September 1996. https://www.epa.gov/sites/production/files/2014-03/documents/fprg.pdf

USEPA, 2009. Underground storage tank program - 25 years of protecting our land and water. EPA-510B-09-001, EPA OSWER, OUST, Washington, DC, March 2009.

https://www.epa.gov/ust/underground-storage-tank-program-25-years-protecting-our-land-and-water

USGS, 1998. Ground water contamination by crude oil near Bemidji, Minnesota. United States Geological Survey, USGS Fact Sheet 084-98. http://mn.water.usgs.gov/projects/bemidji/results/factsheet.pdf

Wiedemeier, T.H., Rifai, H.S., Newell, C.J., Wilson, J.T., 1999. Natural Attenuation of Fuels and Chlorinated Solvents in the Subsurface. John Wiley and Sons, Inc. ISBN: 978-0-471-19749-2, 617 pp. doi:10.1002/9780470172964 


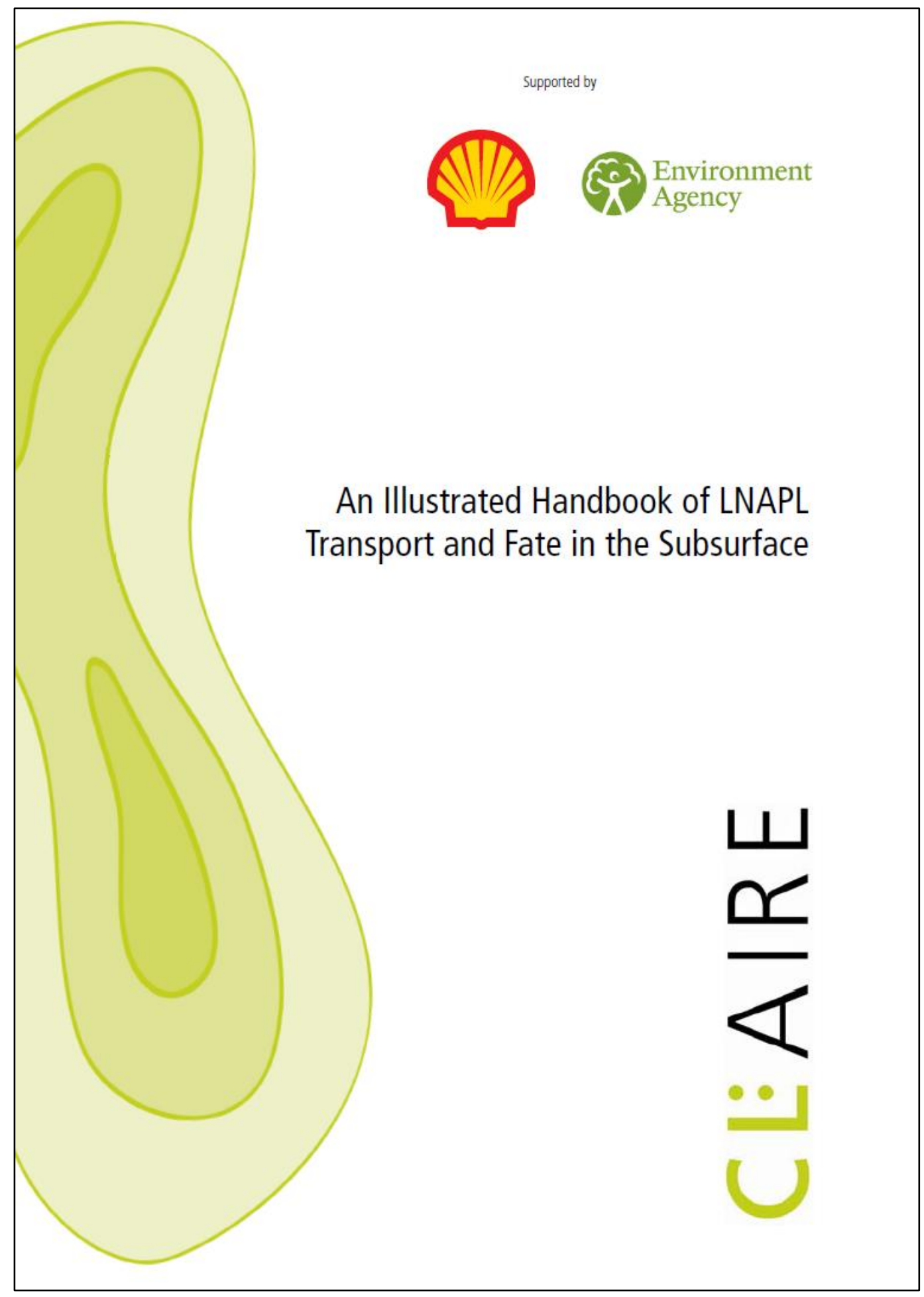

Figure 1. Cover of the LNAPL illustrated handbook, http://www.CL:AIRE.co.uk/LNAPL 


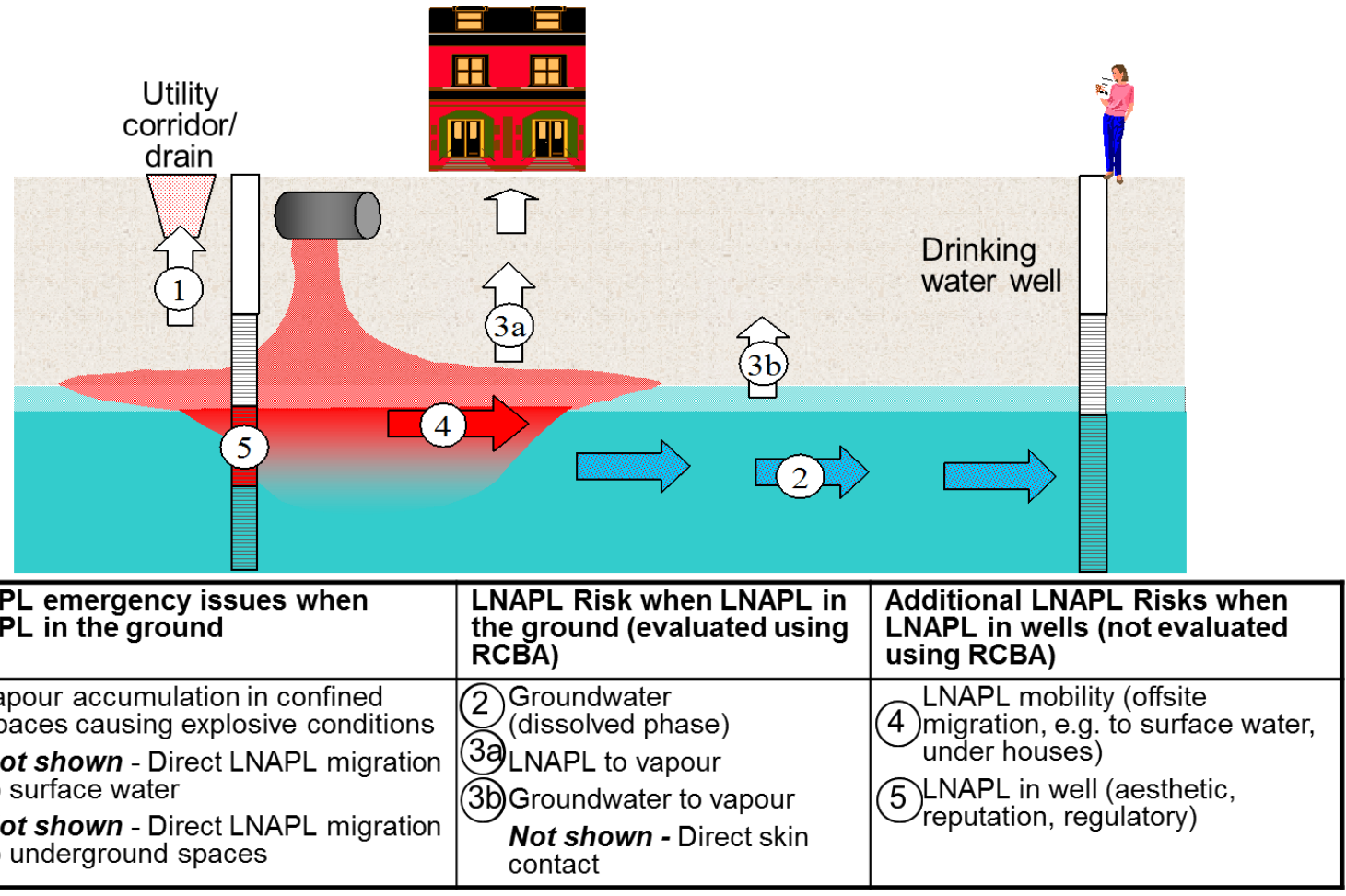

Figure 2. Simplified conceptual site model showing the main composition-based and saturationbased drivers and concerns related to a LNAPL release (Courtesy of S. Garg, Shell, 2009; ITRC, 2016) 


\section{Potential Risk Factors}

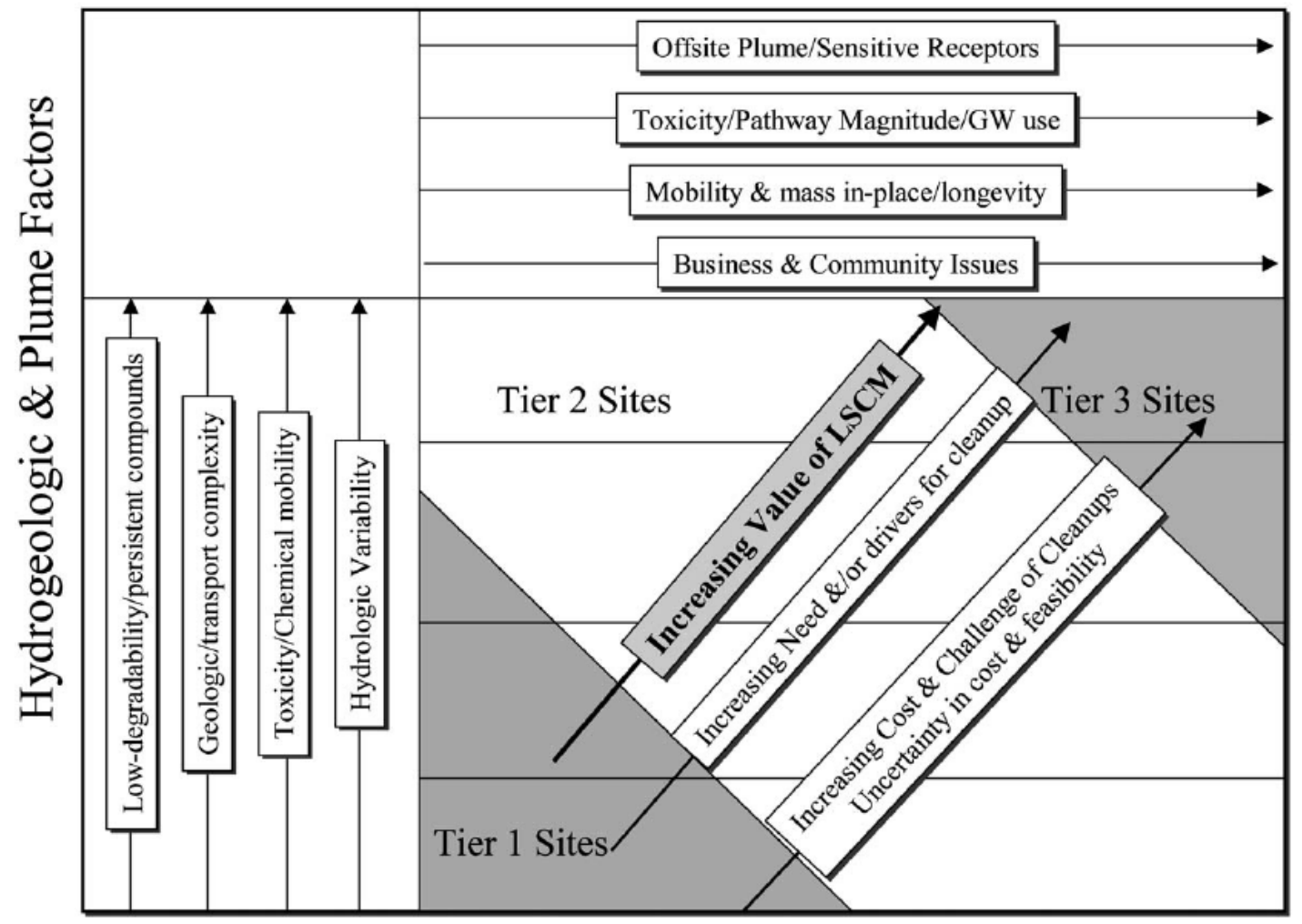

Figure 3. Example factors affecting the conceptual site model for LNAPL sites (Concept after Sale, 2003; ASTM, 2014) 

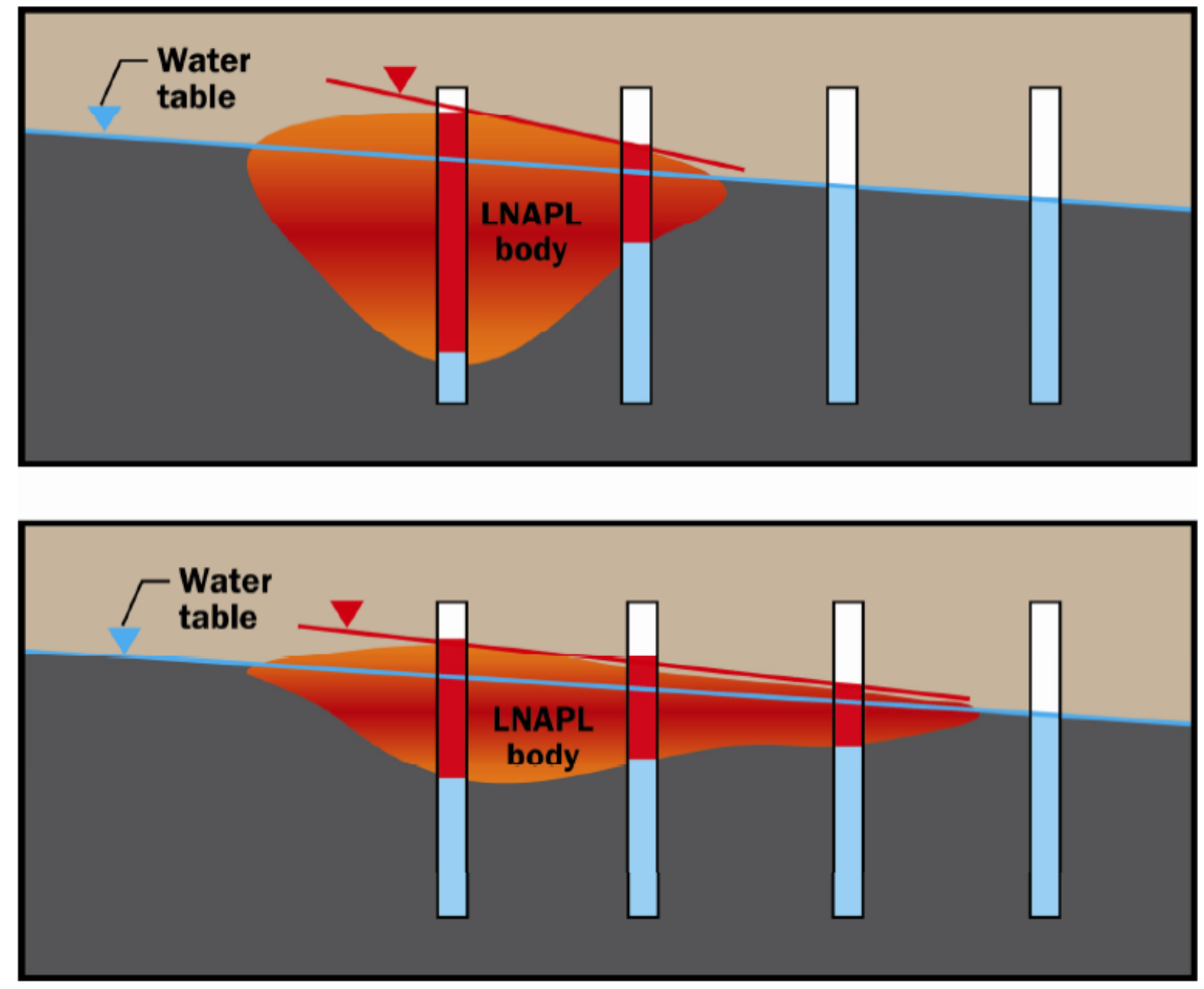

Figure 4. Illustration depicting the evolution of a discrete (i.e., not continuous) LNAPL release. In early time the LNAPL head from the release develops a strong LNAPL gradient shown in the top Figure; as the LNAPL continues to drain from the release lowering the LNAPL head the gradient dissipates and with time will mimic the water table gradient. (Extracted from the LNAPL illustrated handbook, Figure 3.2; CL:AIRE, 2014). 


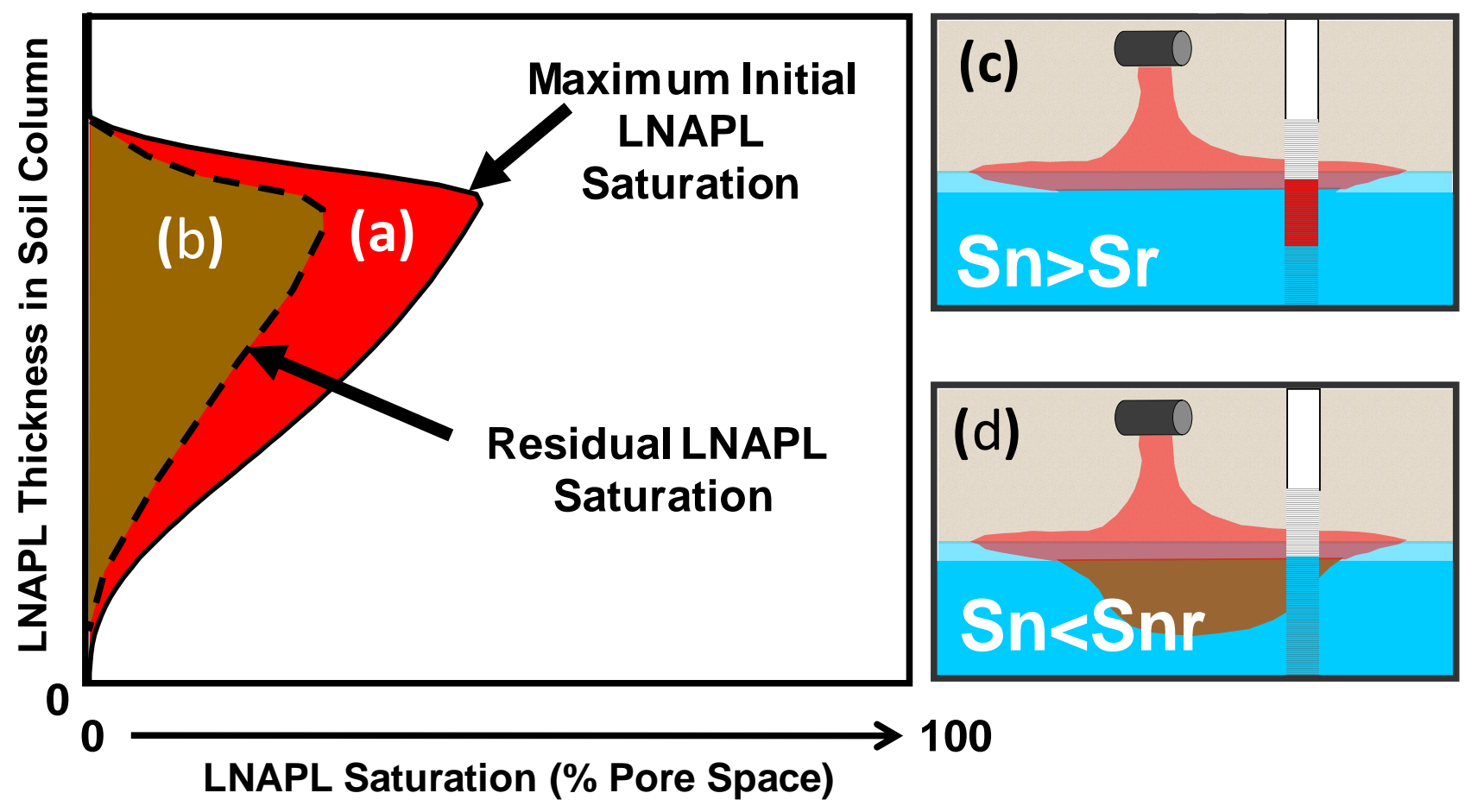

Figure 5. LNAPL saturation profile at the water table interface within an unconfined homogeneous isotropic aquifer is predicted to assume the shape similar to a shark fin under equilibrium conditions when capillary pressures considerations are invoked (Farr et al., 1990; Lenhard and Parker, 1990; CL:AIRE, 2014; ITRC, 2016). (a) Maximum initial LNAPL saturation ( $\mathrm{Sn}$ ) which is greater than the residual saturation shown as (b) based upon a f-factor relationship (Kueper et al., 1993; Steffy et al., 1997). As depicted in (c) when LNAPL saturation ( $\mathrm{Sn}$ ) is above residual ( $\mathrm{Sr}$ ) LNAPL will be observed in a well; whereas, shown in (d) when Sn is less than Sr, LNAPL will not be observed within a well. (Adapted from CL:AIRE, 2014; ITRC, 2016) 


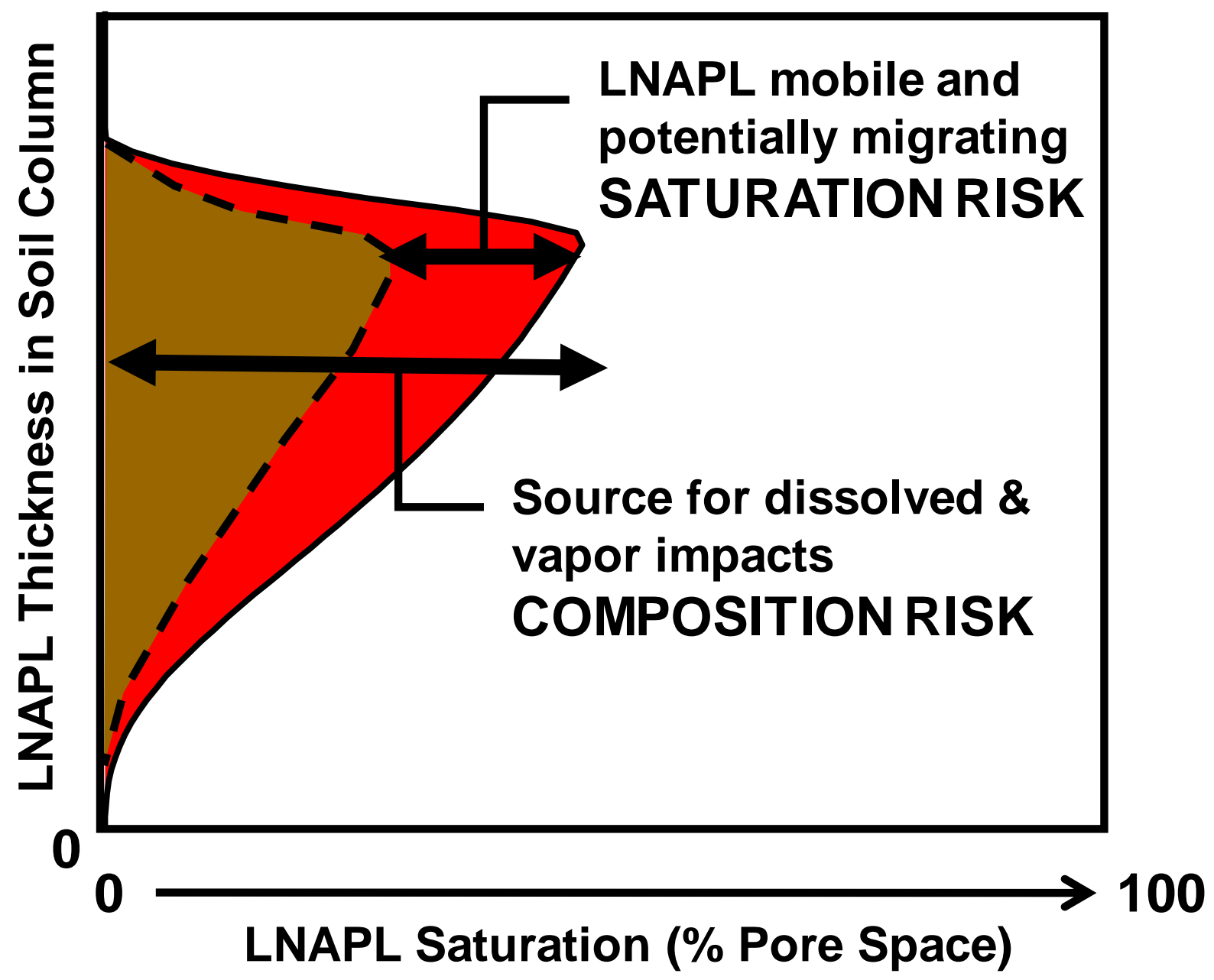

Figure 6. Risks of an LNAPL source include Saturation Risk, which is the portion of the LNAPL source with saturation above residual saturation that is mobile and may potentially migrate (see Figure 5 for clarity). The composition risks include the entire LNAPL source including the residual as well as the mobile fraction are the source of dissolved and vapor impacts. (Adapted from CL:AIRE, 2014; ITRC, 2016) 
a)

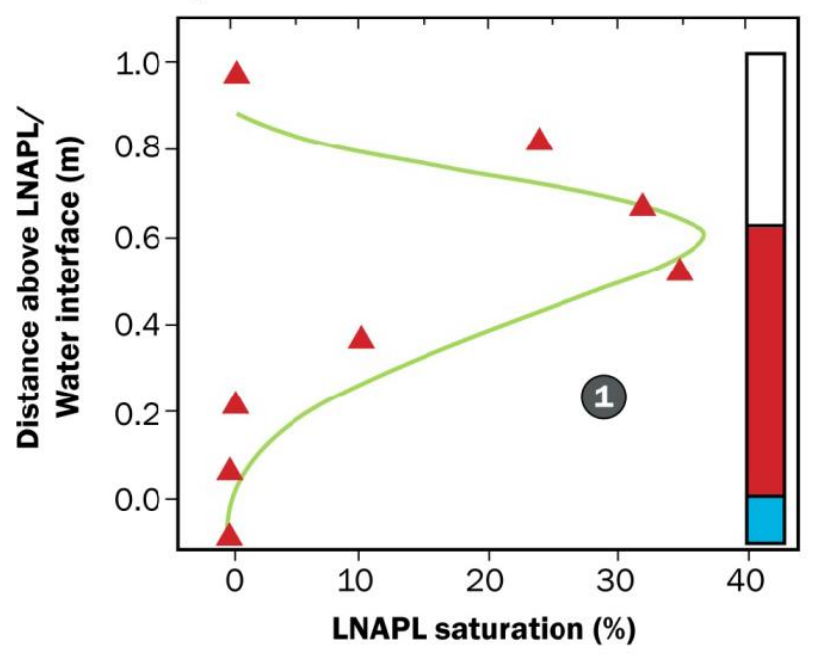

b)

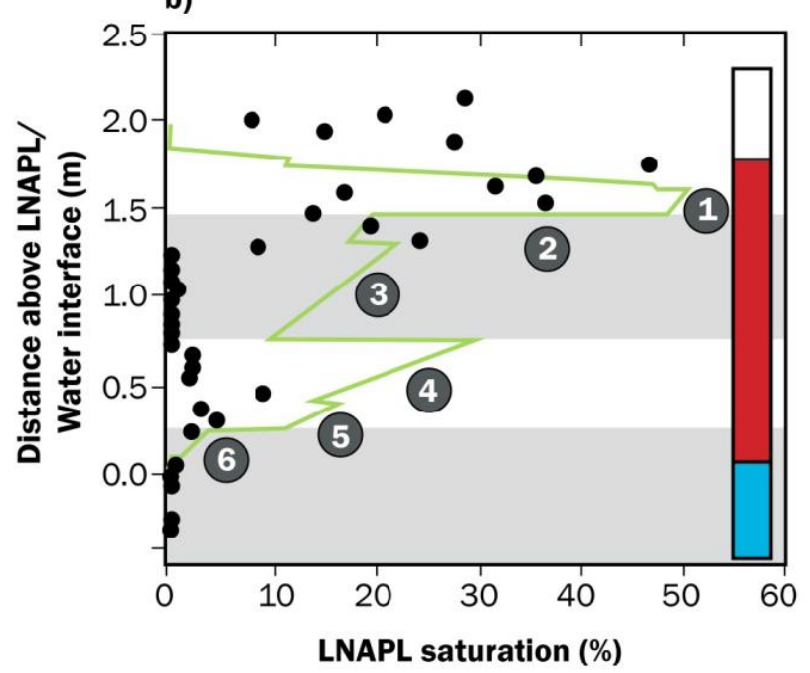

(1) Soil Type

Modelled

Fine-grained Layers

Figure 7. LNAPL saturation near the water table showing observed (symbols) LNAPL saturation compared to vertical equilibrium model simulation predictions (lines). The observed in-well LNAPL thickness is shown for: a) homogeneous (modified from Beckett and Lundegard, 1997); b) a heterogeneous case with finer grained layers (2, 3 and 6) and coarser grained layers (1, 4 and 5) (modified from Huntley et al., 1994a, 1994b). (Extracted from the LNAPL illustrated handbook, Figure 3.5; CL:AIRE; 2014) 


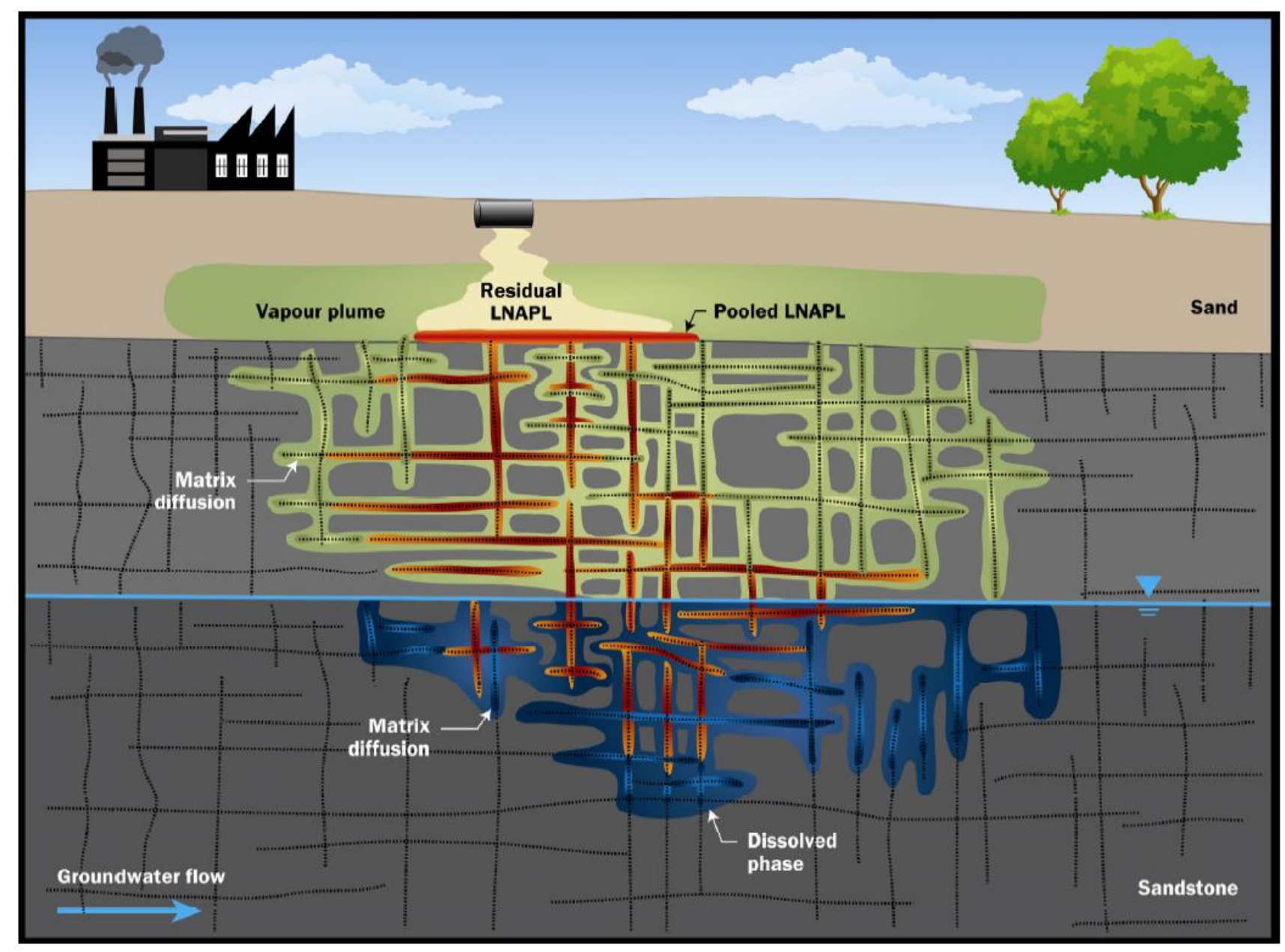

Figure 8. LNAPL release from cemented fractured sandstone (Extracted from the LNAPL illustrated handbook, Figure 5.7; CL:AIRE, 2014). 

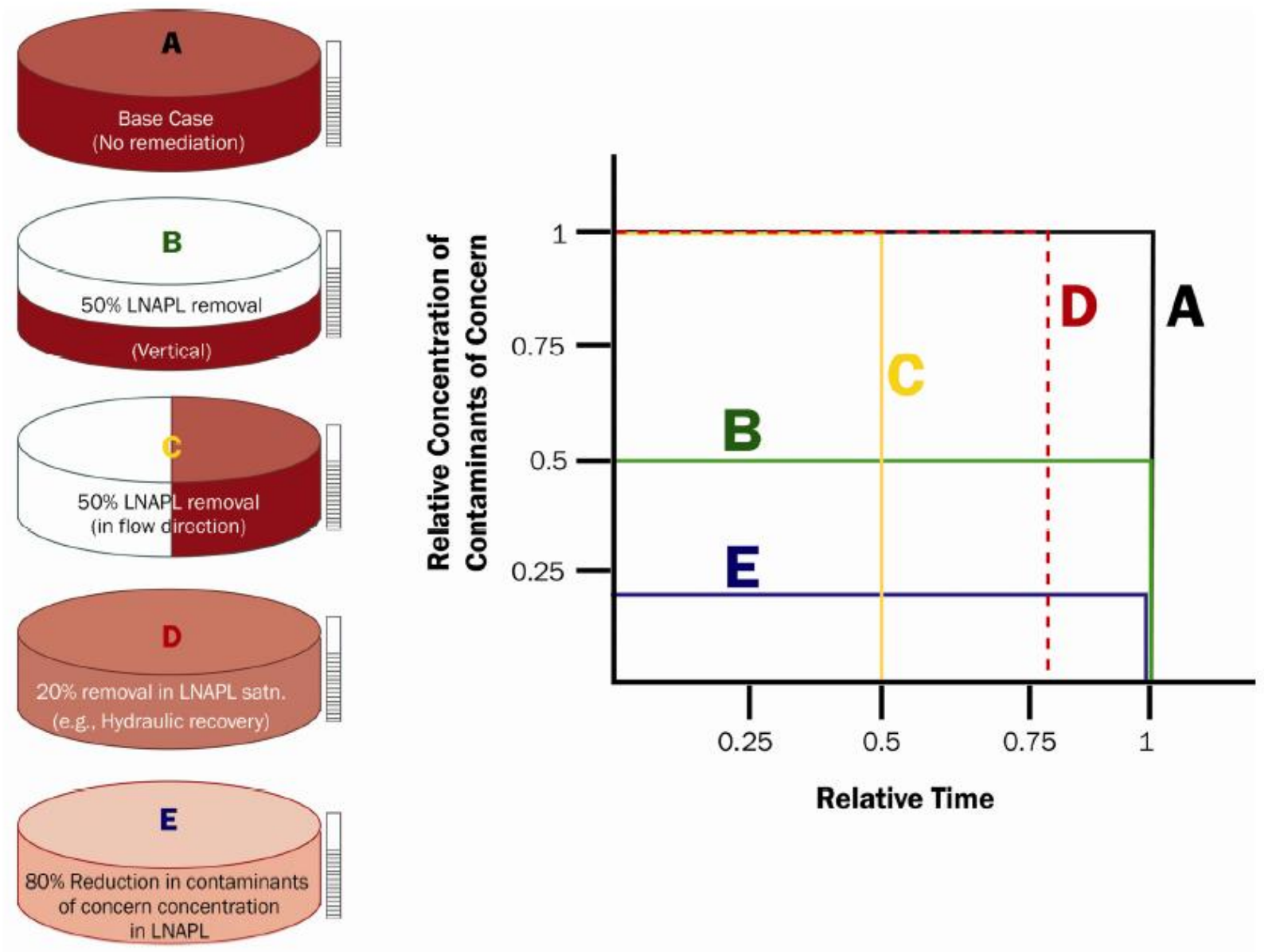

Relative Time

Figure 9. Conceptual effect of partial mass removal on LNAPL constituents in a well down gradient in a number of scenarios including a base case $(A)$ and three scenarios $(B, C, D)$ where NAPL recovery is undertaken and a scenario $(\mathrm{E})$ where the composition is changed (adapted from ITRC, 2009a). The Figure illustrates that, relative to the base case A, NAPL mass recovery (C,D) may affect remediation timescales but not dissolved-phase concentrations, whilst in other circumstances (B) and where contaminant concentrations are reduced $(\mathrm{E})$, relative individual component concentrations but not remedial timescales are reduced (Extracted from the LNAPL illustrated handbook, Figure 7.3; CL:AIRE, 2014). 
Table 1. Exemplar hydrogeological environments (amended extract from the LNAPL illustrated handbook, Table 5.1)

\begin{tabular}{|c|c|c|c|}
\hline $\begin{array}{l}\text { Hydrogeological } \\
\text { environment }\end{array}$ & $\begin{array}{l}\text { Formation } \\
\text { characterization }\end{array}$ & Flow characteristics & $\begin{array}{l}\text { Geological } \\
\text { exemplars }\end{array}$ \\
\hline \multirow{4}{*}{$\begin{array}{l}\text { Intergranular } \\
\text { superficial (drift) } \\
\text { sediments }\end{array}$} & \multirow[t]{2}{*}{ Low heterogeneity } & High permeability & Beach sands \\
\hline & & Low permeability & Marine clays \\
\hline & \multirow[t]{2}{*}{ High heterogeneity } & High permeability & $\begin{array}{l}\text { Glacio-fluvial sands } \\
\text { and gravel }\end{array}$ \\
\hline & & Low permeability & Glacial till \\
\hline \multirow[t]{6}{*}{ Bedrock } & \multirow[t]{3}{*}{ Low matrix porosity } & $\begin{array}{l}\text { Small aperture } \\
\text { fractures }\end{array}$ & $\begin{array}{l}\text { Granite / Igneous } \\
\text { rock }\end{array}$ \\
\hline & & $\begin{array}{l}\text { Large aperture } \\
\text { fractures }\end{array}$ & Karst limestone \\
\hline & & Fracture and matrix & $\begin{array}{l}\text { Cemented sandstone } \\
\text { / gritstone }\end{array}$ \\
\hline & \multirow[t]{3}{*}{ High matrix porosity } & $\begin{array}{l}\text { Small aperture } \\
\text { fractures }\end{array}$ & Chalk \\
\hline & & $\begin{array}{l}\text { Large aperture } \\
\text { fractures }\end{array}$ & Shale / Mudstone \\
\hline & & Fracture and matrix & Sandstone \\
\hline Anthropogenic strata & High heterogeneity & $\begin{array}{l}\text { Both low and high } \\
\text { permeability }\end{array}$ & Made ground, Backfill \\
\hline
\end{tabular}

